\title{
PENGARUH KINERJA KEUANGAN DAN KINERJA SOSIAL TERHADAP HARGA SAHAM DAN VOLUME PERDAGANGAN SAHAM (Studi pada Perusahaan Perbankan Yang Terdaftar di Bursa Efek Indonesia)
}

\author{
Febyareni $^{1}$, \\ Ubud Salim ${ }^{2}$, \\ Achmad Helmy Jawahir ${ }^{3}$ \\ Mahasiswa Magister Manajemen Fakultas Ekonomi dan Bisnis Universitas Brawijaya, \\ Guru Besar Fakultas Ekonomi dan Bisnis Universitas Brawijaya \\ Dosen Fakultas Ekonomi dan Bisnis Universitas Brawijaya \\ e-mail:febyareni@ymail.com
}

\begin{abstract}
ABSTRAK
Penelitian ini bertujuan untuk menganalisis dan menjelaskan pengaruh kinerja keuangan dan kinerja sosial terhadap harga saham dan volume perdagangan saham. Objek penelitian ini adalah perusahaan yang tergabung dalam sektor perbankan yang terdaftar di Bursa Efek Indonesia periode 20112014. Penelitian menggunakan metode kuantitatif dan analisis data menggunakan analisis jalur (path analysis). Pengumpulan data menggunakan data sekunder dari laporan tahunan dan laporan keuangan. Hasil analisis menunjukkan kinerja keuangan yang semakin tinggi mampu meningkatkan harga saham, kinerja sosial yang semakin tinggi mampu meningkatkan harga saham, harga saham yang semakin tinggi mampu meningkatkan volume perdagangan saham, kinerja keuangan tidak memiliki efek terhadap aktivitas volume perdagangan saham, kinerja sosial yang baik mampu meningkatkan volume perdagangan saham perusahaan, kinerja keuangan yang semakin tinggi mampu meningkatkan volume perdagangan saham melalui peningkatan harga saham perusahaan, kinerja sosial yang semakin tinggi mampu meningkatkan volume perdagangan saham melalui peningkatan harga saham perusahaan.
\end{abstract}

Kata kunci: kinerja keuangan, kinerja sosial, harga saham, volume perdagangan saham

\section{PENDAHULUAN}

Kinerja keuangan perusahaan merupakan suatu gambaran mengenai kondisi dan keadaan dari suatu perusahaan yang dianalisis dengan alat-alat analisis keuangan, sehingga dapat diketahui baik atau buruknya kondisi keuangan dan prestasi kerja sebuah perusahaan dalam waktu tertentu. Kinerja keuangan adalah penentuan ukuran- ukuran tertentu yang dapat mengukur keberhasilan suatu perusahaan dalam menghasilkan laba (Sucipto, 2003). Pengukuran laba yang ditinjau dari aset dan modal yang dimiliki menunjukkan kemampuan perusahaan tersebut mampu atau tidak mengelola aset yang ada (Laurensia, 2015).

Kinerja sosial perusahaan adalah penilaian kinerja sebuah perusahaan dilihat dari peran sosial CSR yang dimainkannya ditengah masyarakat. Semakin 
sebuah perusahaan mengimplementasikan CSR dan komponen terkait dengan baik, maka kinerja sosial perusahaan tersebut akan semakin terangkat. Hasil yang diharapkan, tentu kembali kepada perusahaan dalam bentuk dukungan publik dan penguatan faktor sosial terhadap pengelolaan dan pembangunan yang berkelanjutan (sustainable development) dari masyarakat terhadap perusahaan yang bersangkutan (Karimi, 2009). Apabila perusahaan memiliki kinerja lingkungan dan sosial yang buruk, maka akan muncul keraguan dari investor sehingga direspon negatif melalui penurunan harga saham (Rustiarini, 2010 dalam Vijaya 2012). Semakin baik suatu perusahaan melakukan pengungkapan CSR maka akan semakin kuat respon yang akan diberikan perusahaan kepada stakeholder maupun shareholder.

Volume perdagangan saham merupakan hal yang penting bagi investor karena menggambarkan tingkat likuiditas suatu saham (Wiyani dan Wijayanto, 2005). Semakin besar volume transaksi, maka semakin cepat dan semakin mudah sebuah saham diperjualbelikan, sehingga transformasi saham menjadi kas semakin cepat pula. Transformasi inilah esensi dari likuiditas saham. Volume perdagangan saham menggambarkan reaksi pasar secara langsung. Volume perdagangan saham menunjukkan banyaknya lembar saham yang ditransaksikan selama periode waktu tertentu (Tandelilin, 2001).

\section{Kinerja Keuangan Perusahaan}

Kinerja perusahaan merupakan hasil dari banyak keputusan individual yang dibuat secara terus menerus oleh pihak manajemen suatu perusahaan (Helfert: 1996). Secara implisit definisi kinerja mengandung suatu pengertian adanya suatu efisiensi yang dapat diartikan secara umum sebagai rasio atau perbandingan antara masukan dan keluaran. Kinerja perusahaan sebagai emiten di pasar modal merupakan prestasi yang dicapai perusahaan yang menerbitkan saham yang mencerminkan kondisi keuangan dan hasil operasi (operating result) perusahaan tersebut dan biasanya diukur dalam rasio-rasio keuangan. Jadi, kinerja keuangan adalah penentuan ukuran - ukuran tertentu yang dapat mengukur keberhasilan suatu perusahaan dalam menghasilkan laba (Sucipto, 2003).

Pengukuran kinerja keuangan perusahaan dengan menggunakan ukuran rasio sudah menjadi suatu parameter yang terbilang umum saat ini. Rasio menggambarkan suatu hubungan atau perimbangan (mathematical relationship) antara suatu jumlah tertentu dengan jumlah yang lain (Munawir, 2000: 54). Dalam penelitian-penelitian yang berkaitan dengan penilaian kinerja perusahaan umumnya para peneliti dalam memilih proksi kinerja perusahaan dilakukan berdasarkan pada ketentuan: (1) hasil penelitian-penelitian sejenis sebelumnya, (2) menggunakan tolok ukur yang telah ditetapkan oleh otoritas yang berwenang, (3) kelaziman dalam praktek, dan (4) mengembangkan model pengukuran melalui pengujian secara statistik terlebih dahulu dengan memilih tolok ukur yang sesuai dengan tujuan penelitian. Rasio sebenarnya hanyalah alat yang dinyatakan dalam aritmathical terms yang dapat digunakan untuk menjelaskan hubungan antara dua macam data financial. Rasio keuangan merupakan suatu informasi yang menggambarkan hubungan antara berbagai macam akun (accounts) dari 
laporan keuangan yang mencerminkan keadaan keuangan serta hasil operasional perusahaan.

Menurut Ang (1997) rasio keuangan dapat dikelompokkan menjadi lima jenis berdasarkan ruang lingkup atau tujuan yang ingin dicapai, yaitu : (1) Rasio Likuiditas (Liquidity Ratios), (2) Rasio Aktivitas (Activity Ratios), (3) Rasio Rentabilitas/Profitabilitas (Profitability Ratios), (4) Rasio Solvabilitas (Solvency Ratios), (5) Rasio Pasar (Market Ratios).

\section{Kinerja Sosial Perusahaan}

Sukarno (2008) menyatakan bahwa kinerja sosial perusahaan merupakan seperangkat hasil yang dicapai dan merujuk pada tindakan pencapaian serta pelaksanaan suatu tanggung jawab sosial yang diharapkan dari perusahaan. Igalens dan Gond (2005) yang menyatakan bahwa kinerja sosial perusahaan merupakan suatu konstruk yang digambarkan dengan cara-cara yang berbeda. Kinerja sosial perusahaan adalah suatu konstruk multidimensional yang didefinisikan oleh Caroll (1979) memiliki empat komponen tanggung jawab sosial perusahaan, antara lain: tanggung jawab ekonomi kepada investor dan konsumen, tanggung jawab legal kepada pemerintah atau hukum, tanggung jawab etis kepada masyarakat, dan tanggung jawab philantrophic kepada komunitas. Model kinerja sosial perusahaan mencerminkan suatu interaksi yang mendasar diantara prinsip tanggung jawab sosial, proses dari social responsiveness, dan kebijakan yang berkembang atas dampak dari isu-isu sosial. Wood (1991) mengembangkan suatu model kinerja sosial perusahaan atau corporate social performance sebagai berikut :

\section{Tabel 1}

Model Kinerja Sosial Perusahaan

\begin{tabular}{|c|}
\hline $\begin{array}{c}\text { Model Kinerja Sosial Perusahaan Prinsip Corporate Social } \\
\text { Responsibility }\end{array}$ \\
\hline Prinsip institusional: legitimasi \\
Prinsip organisasional: tanggung jawab publik \\
Prinsip individual: pertimbangan manajemen \\
\hline Proses Corporate Social Responsiveness \\
\hline Penilaian lingkungan \\
Manajemen stakeholder \\
Manajemen isu \\
\hline Hasil Corporate Behaviour \\
\hline Dampak social \\
Program sosial \\
Kebijakan sosial \\
\hline
\end{tabular}

\section{Harga Saham}

Jogiyanto (2007: 11) menyatakan bahwa saham merupakan bukti pemilikan sebagian dari perusahaan. Saham merupakan salah satu produk yang diperjualbelikan di pasar modal yang dapat didefinisikan sebagai tanda penyertaan atau kepemilikan seseorang atau badan dalam suatu perusahaan atau perusahaan terbatas yang berwujud berupa selembar kertas yang menerangkan siapa 
pemiliknya. Sistem kepemilikan saham di BEI saat ini tanpa menggunakan warkat, dimana bentuk kepemilikan tidak lagi berupa lembaran saham yang diberi nama pemiliknya, tetapi sudah berupa account atas nama pemilik atau saham tanpa warkat, sehingga penyelesaian transaksi akan semakin cepat dan mudah.

\section{Aktivitas Volume Perdagangan Saham}

Akitifitas volume perdagangan saham (Trading Volume Activity) diartikan sebagai jumlah lembar saham yang diperdagangkan pada hari tertentu (Abdul dan Nasuhi, 2000). Akitifitas volume perdagangan saham merupakan suatu instrumen yang dapat digunakan untuk melihat reaksi pasar modal terhadap informasi melalui parameter pergerakan aktivitas volume perdagangan saham di pasar. Perubahan permintaan saham mempunyai pengaruh terhadap volume perdagangan saham, karena perkembangan pasar modal terutama di pasar sekunder tidak lepas dari peran para investor (sisi permintaan di pasar modal). Semakin banyak dan semakin besar para investor menginvestasikan modalnya pada saham akan menjadikan saham-saham yang diperdagangkan semakin likuid, maka likuidnya saham-saham yang diperdagangkan akan mengundang banyak investor untuk menginvestasikan modalnya di saham. Volume perdagangan saham merupakan bagian yang diterima dalam analisis teknikal.

\section{Kerangka Konsep Penelitian}

\section{Gambar 1}

Kerangka Konsep Penelitian

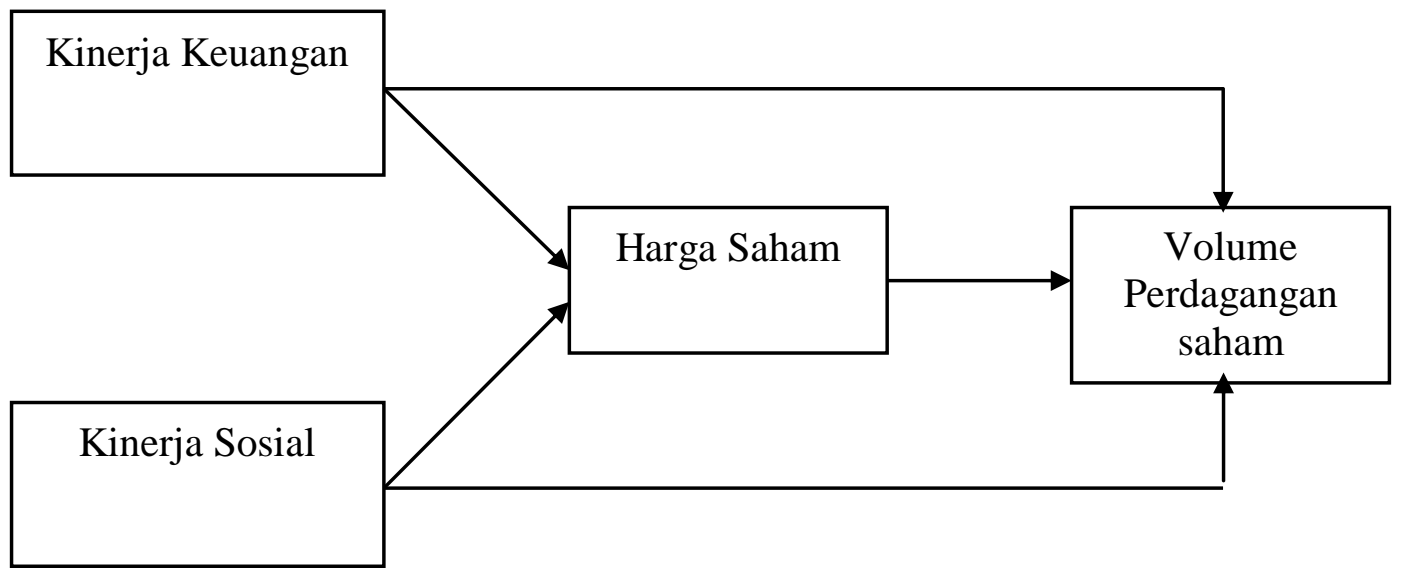

\section{Hipotesis Penelitian}

Berdasarkan pada kerangka konsep penelitian maka hipotesis penelitian yang disusun berdasarkan model konseptual dan penjabaran hubungan antar variabel penelitian-penelitian terdahulu seperti di bawah ini :

\section{Tabel 2}

Mapping Sumber Hipotesis

\begin{tabular}{|c|c|c|}
\hline No. & Hipotesis Penelitian & Tinjauan Empiris \\
\hline \multirow{2}{*}{1} & Kinerja Keuangan & Astria (2007); Riantani et al., (2011); Zuliarni \\
& terhadap & (2013); Affif dan Anantadjaya (2013); \\
& Harga Saham (H1) & (2013); Peter dan Robin (2011); \\
\hline
\end{tabular}




\begin{tabular}{|c|c|c|}
\hline & & Hariandy (2010) \\
\hline 2 & $\begin{array}{c}\text { Kinerja Sosial } \\
\quad \text { terhadap } \\
\text { Harga Saham }(\mathrm{H} 2)\end{array}$ & $\begin{array}{c}\text { Afiff dan Anantadjaya (2013); Nuryaman } \\
\text { (2013); Vijaya (2012); Cellier dan Chollet } \\
\text { (2010) }\end{array}$ \\
\hline No. & Hipotesis Penelitian & Tinjauan Empiris \\
\hline 3 & $\begin{array}{c}\text { Harga Saham } \\
\text { terhadap } \\
\text { Volume Perdagangan Saham }(\mathrm{H} 3)\end{array}$ & $\begin{array}{l}\text { Pathirawasam (2011); Tripathy (2011); Bajaj } \\
\text { dan Dua (2014) }\end{array}$ \\
\hline 4 & $\begin{array}{c}\text { Kinerja Keuangan } \\
\text { terhadap } \\
\text { Volume Perdagangan Saham }(\mathrm{H} 4) \\
\end{array}$ & $\begin{array}{l}\text { Monang (1999); Astria (2007); Hermawan } \\
\text { (2009); Aldorino et al., (2013) }\end{array}$ \\
\hline 5 & $\begin{array}{c}\text { Kinerja Sosial } \\
\text { terhadap } \\
\text { Volume Perdagangan Saham (H5) }\end{array}$ & $\begin{array}{c}\text { Hermawan (2009); Aldorino et al., (2013); } \\
\text { Vijaya (2012) }\end{array}$ \\
\hline 6 & $\begin{array}{c}\text { Kinerja Keuangan } \\
\text { terhadap } \\
\text { Volume Perdagangan Saham } \\
\text { melalui Harga Saham (H6) }\end{array}$ & $\begin{array}{l}\text { Pathirawasam (2011); Vijaya (2012), Tripathy } \\
\text { (2011); Bajaj dan Dua (2014) }\end{array}$ \\
\hline 7 & $\begin{array}{c}\text { Kinerja Sosial } \\
\text { terhadap } \\
\text { Volume Perdagangan Saham } \\
\text { Melalui Harga Saham }(\mathrm{H} 7)\end{array}$ & Vijaya (2012); Aldorino et al., (2013) \\
\hline
\end{tabular}

Berdasarkan penjelasan tersebut maka dapat dihipotesiskan bahwa

$\mathrm{H}_{1}$ : Meningkatnya kinerja keuangan akan mampu meningkatkan harga saham

$\mathrm{H}_{2}$ : Meningkatnya kinerja sosial akan mampu meningkatkan harga saham

$\mathrm{H}_{3}$ : Meningkatnya harga saham akan mampu meningkatkan volume perdagangan saham

$\mathrm{H}_{4}$ : Meningkatnya kinerja keuangan akan mampu meningkatkan volume perdagangan saham

$\mathrm{H}_{5}$ : Meningkatnya kinerja sosial akan mampu meningkatkan volume perdagangan saham

$\mathrm{H}_{6}$ : Meningkatnya kinerja keuangan akan mampu meningkatkan volume perdagangan saham melalui peningkatan harga saham

$\mathrm{H}_{7}$ : Meningkatnya kinerja sosial akan mampu meningkatkan volume perdagangan saham melalui peningkatan harga saham

\section{METODE PENELITIAN}

\section{Jenis dan Pendekatan Penelitian}

Penelitian ini adalah penelitian kuantitatif. Jenis penelitian berdasarkan tujuan asosiatif. Berdasarkan tingkat eksplanasinya adalah eksplanatori. Menurut Sugiyono (2012: 21) penelitian eksplanatori merupakan penelitian yang bermaksud menjelaskan kedudukan variabel-variabel yang diteliti serta hubungan antara satu variabel dengan yang lain.

\section{Populasi Penelitian}

Penelitian ini menggunakan metode sensus karena seluruh anggota populasi masuk ke dalam objek kajian penelitian. Untuk mendapatkan suatu 
populasi survei yang sesuai pada penelitian ini diberlakukan kriteria populasi, sebagai berikut:

a. Saham-saham perusahaan publik dalam sektor perbankan yang terdaftar di PT Bursa Efek Indonesia (BEI) pada periode tahun 2011-2014 secara berturut-turut.

b. Saham-saham perusahaan publik dalam sektor perbankan yang terdaftar di PT Bursa Efek Indonesia (BEI) yang mempublikasikan laporan keuangan yang berisi data lengkap tentang harga penutupan saham (closing price), volume perdagangan saham, jumlah saham yang beredar, yang mengungkapkan tanggung jawab sosial berupa CSR dan laporan kinerja keuangan yang berkaitan dengan perhitungan Return On Asset (ROA) pada periode tahun 2011-2014 secara berturut-turut.

Jumlah perusahaan yang memenuhi kriteria menjadi populasi survei dalam penelitian ini ada 19 perusahaan sebagai berikut :

\section{Tabel 3}

Objek Penelitian

\begin{tabular}{|c|l|c|}
\hline No. & \multicolumn{1}{|c|}{ Nama Perusahaan } & Kode Perusahaan \\
\hline 1 & Bank Central Asia Tbk & BBCA \\
\hline 2 & Bank Bukopin Tbk & BBKP \\
\hline 3 & Bank Negara Indonesia (Persero) & BBNI \\
\hline 4 & Bank Tabungan Negara (Persero) & BBTN \\
\hline 5 & Bank Rakyat Indonesia (Persero) & BBRI \\
\hline 6 & Bank Danamon Tbk & BDMN \\
\hline 7 & BPD Jawa Barat dan Banten Tbk & BJBR \\
\hline 8 & Bank Mandiri (Persero) Tbk & BMRI \\
\hline 9 & Bank CIMB Niaga Tbk & BNGA \\
\hline 10 & Bank Internasional Indonesia Tbk & BNII \\
\hline 11 & Bank Permata Tbk & BNLI \\
\hline 12 & Bank Sinarmas Tbk & BSIM \\
\hline 13 & Bank Tabungan Pensiunan Nasional Tbk & BTPN \\
\hline 14 & Bank Victoria International & BVIC \\
\hline 15 & Bank Artha Graha Internasional Tbk & INPC \\
\hline 16 & Bank Mega Tbk & MEGA \\
\hline 17 & Bank OCBC NISP Tbk & NISP \\
\hline 18 & Bank Pan Indonesia Tbk & SDRA \\
\hline 19 & Bank Saudara Tbk & \\
\hline
\end{tabular}

Sumber: ICMD 2011-2014, data diolah

\section{Teknik Pengukuran dan Skala Pengukuran Variabel}

Penelitian ini menggunakan lima variabel yang diukur menggunakan suatu proksi tertentu dengan formulanya masing-masing. Berikut adalah teknik pengukuran dan skala pengukuran variabel yaitu: 
Tabel 4

Uraian Variabel Penelitian

\begin{tabular}{|c|c|c|c|}
\hline $\begin{array}{l}\mathbf{N} \\
\mathbf{0 .}\end{array}$ & Variabel & Pengukuran & Sumber \\
\hline \multirow[b]{2}{*}{1.} & \multirow{2}{*}{$\begin{array}{l}\text { Kinerja } \\
\text { Keuangan } \\
\qquad\left(\mathrm{X}_{1}\right)\end{array}$} & \multirow{2}{*}{$\mathrm{ROA}=\frac{\text { Laba Bersih (Earning After Interest and Ti }}{\text { Jumlah Aktiva (Total Assets) }}$} & \multirow{2}{*}{$\begin{array}{l}\text { (Brigham dan } \\
\text { Houston } \\
\text { 2006:109); } \\
\text { (Brigham dan } \\
\text { Daves, 2007: } \\
\text { 261); (Kasmir, } \\
\text { 2008: 202) }\end{array}$} \\
\hline & & & \\
\hline 2. & $\begin{array}{c}\text { Kinerja } \\
\text { Sosial }\left(\mathrm{X}_{2}\right)\end{array}$ & $\operatorname{CSRDI} I_{j}=\frac{\sum X_{i j}}{n_{j}}$ & $\begin{array}{c}\text { Haniffa dan } \\
\text { Cooke (2005) }\end{array}$ \\
\hline 3. & $\begin{array}{c}\text { Harga } \\
\text { Saham (Zn) }\end{array}$ & closing price akhir periode tahunan & $\begin{array}{c}\text { Jogiyanto } \\
(2008)\end{array}$ \\
\hline 4. & $\begin{array}{l}\text { Volume } \\
\text { Perdagangan } \\
\text { saham }(Y)\end{array}$ & $\begin{array}{l}Y= \\
\frac{\sum \text { saham perwsahaan }_{i} \text { yang diperdaganghan pada wahtu }}{\text { Esahamperusahaan }} \\
\end{array}$ & $\begin{array}{l}\text { Bandi dan } \\
\text { Hartono (1999); } \\
\text { Vijaya (2012) }\end{array}$ \\
\hline
\end{tabular}

\section{Metode Pengumpulan Data}

Metode yang dilakukan berupa metode dokumentasi. Sumber data yang digunakan adalah data sekunder yang berupa laporan tahunan yang telah dipublikasikan beserta harga saham dari perusahaan objek penelitian pada saat harga penutupan saham (closing price) akhir periode tahunan.

\section{Metode Analisis Data \\ Uji Normalitas}

Uji normalitas bertujuan untuk menguji apakah dalam model regresi, variabel dependen dan variabel independen keduanya mempunyai distribusi normal ataukah tidak. Model regresi yang baik adalah memiliki distribusi data normal atau mendekati normal.

\section{Uji Linearitas}

Uji linearitas ada karena untuk menggunakan analisis jalur pertimbangan yang digunakan salah satunya model persamaan harus linier. Pada penelitian ini penulis menggunakan Uji Lagrange Multiplier. Uji ini merupakan uji alternative dari Ramsey test dan dikembangkan oleh Engle pada tahun 1982. Estimasi uji ini bertujuan untuk mendapatkan nilai $\mathrm{c}^{2}$ hitung atau ( $\mathrm{n} \times \mathrm{R}^{2}$ ). (Ghozali, 2011: 169)

\section{Analisis Jalur (Path Analysis)}

Sarwono (2007: 1) Analisis jalur merupakan pengembangan dari analisis regresi, sehingga analisis regresi dapat dikatakan sebagai bentuk khusus dari analisis jalur (regression is special case of path analysis). Penelitian ini mengelompokkan variabel penelitian kedalam variabel endogen dan eksogen.

\section{HASIL DAN PEMBAHASAN}

Uji Normalitas 
Tabel 5

Uji Normalitas Kolmogorov-Smirnov

\begin{tabular}{|c|c|c|c|}
\hline Model & Kolmogorov-Smirnov $\boldsymbol{Z}$ & $\boldsymbol{p}$-value & Keterangan \\
\hline 1 & 0,838 & 0,483 & Normal \\
\hline 2 & 1,070 & 0,202 & Normal \\
\hline
\end{tabular}

Uji Linieritas

Sumber: Data Diolah (2015)

Tabel 6

Uji Linieritas

\begin{tabular}{|ccc|c|c|c|}
\hline \multicolumn{3}{|c|}{ Variabel } & F-hitung & $\boldsymbol{p}$-value & Ket \\
\hline Kinerja Keuangan & $\rightarrow$ & Harga Saham & 79,033 & 0,000 & Linier \\
\hline Kinerja Sosial & $\rightarrow$ & Harga Saham & 79,225 & 0,000 & Linier \\
\hline Kinerja Keuangan & $\rightarrow$ & Volume Perdagangan Saham & 13,408 & 0,000 & Linier \\
\hline Kinerja Sosial & $\rightarrow$ & Volume Perdagangan Saham & 29,913 & 0,000 & Linier \\
\hline Harga Saham & $\rightarrow$ & Volume Perdagangan Saham & 31,614 & 0,000 & Linier \\
\hline
\end{tabular}

Analisis Jalur

Sumber: Data Diolah (2015)

Penelitian ini menggunakan analisis jalur (path) untuk menguji pengaruh kinerja keuangan dan kinerja sosial terhadap harga saham dan pengaruh kinerja keuangan, kinerja sosial, dan harga saham terhadap volume perdagangan saham.

Gambar 2

\section{Diagram Analisis Jalur}

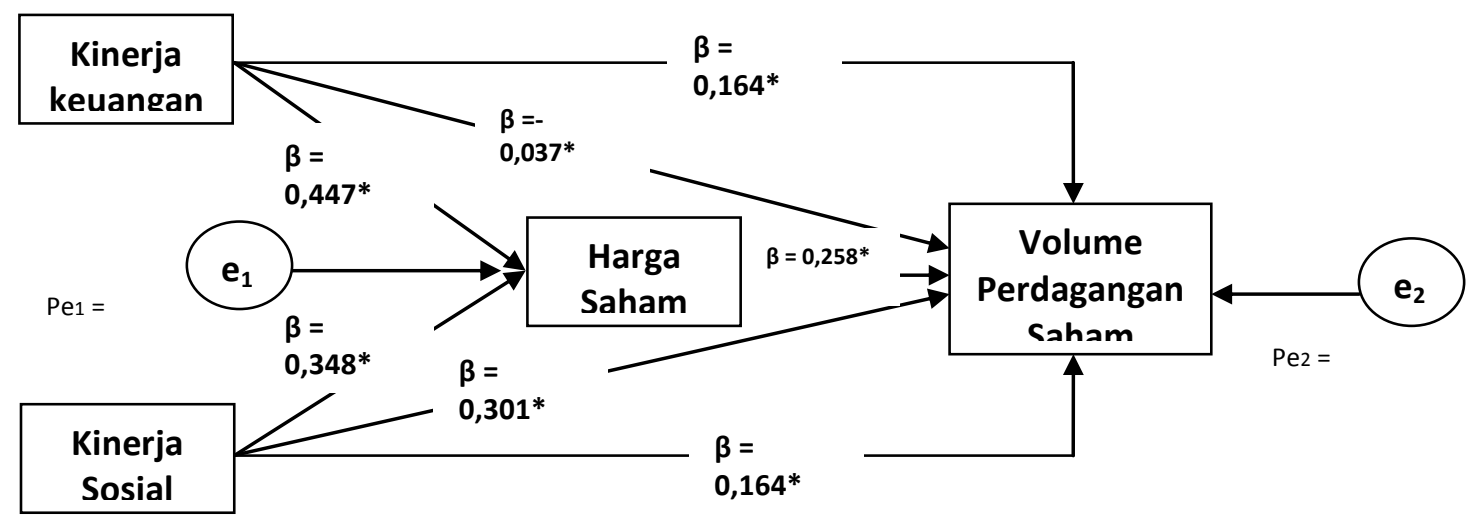

Berdasarkan Gambar 2 terlihat bahwa model penelitian menggunakan analisis jalur dibentuk oleh empat variabel yaitu Kinerja Keuangan, Kinerja Sosial, Harga Saham, dan Volume Perdagangan Saham. Berikut disajikan hasil pengaruh antar variabel yang diamati.

Tabel 6

Pengaruh Antar Variabel

\begin{tabular}{|c|c|c|c|c|c|}
\hline Pengaruh & $\begin{array}{c}\text { Koefisi } \\
\text { en }\end{array}$ & t-hitung & p-value & $\mathbf{R}^{2}$ & Signifikansi \\
\hline $\begin{array}{c}\text { Kinerja Keuangan } \rightarrow \text { Harga } \\
\text { Saham }\end{array}$ & 0,447 & 5,479 & 0,000 & \multirow{2}{*}{$\begin{array}{c}75,8 \\
\%\end{array}$} & Signifikan Positif \\
\hline Kinerja Sosial $\rightarrow$ Harga Saham & 0,348 & 5,490 & 0,000 & & Signifikan Positif \\
\hline
\end{tabular}




\begin{tabular}{|c|c|c|c|c|c|}
\hline Total & & & & & \\
\hline $\begin{array}{c}\text { Kinerja Keuangan } \rightarrow \text { Volume } \\
\text { Perdagangan Saham }\end{array}$ & $-0,037$ & 0,268 & 0,790 & \multirow{4}{*}{$\begin{array}{c}24,2 \\
\%\end{array}$} & $\begin{array}{c}\text { Tidak Signifikan } \\
\text { Negatif }\end{array}$ \\
\hline $\begin{array}{l}\text { Kinerja Sosial } \rightarrow \text { Volume } \\
\text { Perdagangan Saham }\end{array}$ & 0,301 & 2,171 & 0,033 & & Signifikan Positif \\
\hline $\begin{array}{l}\text { Harga Saham } \rightarrow \text { Volume } \\
\text { Perdagangan Saham }\end{array}$ & 0,258 & 2,189 & 0,020 & & Signifikan Positif \\
\hline Total & & & & & \\
\hline
\end{tabular}

\section{Pengujian Hipotesis}

\section{Pengaruh Kinerja Keuangan terhadap Harga Saham}

Hasil analisis menunjukkan terdapat pengaruh positif dan signifikan antara kinerja keuangan terhadap harga saham yang ditunjukkan dari nilai t-hitung $(5,479)$ lebih besar dari t-tabel $(1,960)$ dan $p$-value $(0,000)$ lebih kecil dari alpha $5 \%(0,050)$. Untuk koefisien jalur $(\beta=0,447)$ menunjukkan bahwa meningkatnya kinerja keuangan akan meningkatkan harga saham secara signifikan, dan sebaliknya menurunnya kinerja keuangan akan menurunkan harga saham secara signifikan, sehingga hipotesis diterima. Hasil ini menunjukkan bahwa dengan semakin meningkatnya kinerja keuangan berdasarkan keuntungan perusahaan yang diperoleh dari memanfaatkan keseluruhan aset mampu mencerminkan kondisi perusahaan yang baik sehingga perusahaan perbankan yang terdaftar di Bursa Efek Indonesia dapat memiliki kesempatan untuk meningkatkan harga saham yang semakin tinggi.

\section{Pengaruh Kinerja Sosial terhadap Harga Saham}

Hasil analisis menunjukkan terdapat pengaruh positif dan signifikan antara kinerja sosial terhadap harga saham yang ditunjukkan dari nilai t-hitung $(5,490)$ lebih besar dari t-tabel $(1,960)$ dan p-value $(0,000)$ lebih kecil dari alpha $5 \%$ $(0,050)$. Untuk koefisien jalur $(\beta=0,348)$ menunjukkan bahwa meningkatnya kinerja sosial akan meningkatkan harga saham secara signifikan, dan sebaliknya menurunnya kinerja sosial akan menurunkan harga saham secara signifikan, sehingga hipotesis diterima. Hasil penelitian ini menunjukkan bahwa dengan semakin meningkatnya kinerja sosial maka perusahaan perbankan yang terdaftar di Bursa Efek Indonesia memiliki kesempatan untuk meningkatkan harga saham selama manajemen mampu melakukan pengungkapan penerapan kegiatan CSR yang konsisten dan berkelanjutan sehingga penerapan CSR dianggap sebagai investasi dan bukan sebagai beban yang mengurangi keuntungan.

\section{Pengaruh Harga Saham terhadap Volume Perdagangan Saham}

Hasil analisis menunjukkan terdapat pengaruh positif dan signifikan antara harga saham terhadap volume perdagangan saham yang ditunjukkan dari nilai thitung $(2,189)$ lebih besar dari t-tabel $(1,960)$ dan $p$-value $(0,020)$ lebih kecil dari alpha 5\% (0,050). Untuk koefisien jalur $(\beta=0,258)$ menunjukkan bahwa meningkatnya harga saham akan meningkatkan volume perdagangan saham secara signifikan, dan sebaliknya menurunnya harga saham akan menurunkan volume perdagangan saham secara signifikan, sehingga hipotesis diterima. Hasil penelitian ini menunjukkan bahwa dengan semakin meningkatnya harga saham 
maka perusahaan perbankan yang terdaftar di Bursa Efek Indonesia memiliki kesempatan untuk meningkatkan volume perdagangan saham. Semakin tinggi harga saham perusahaan menandakan bahwa perusahaan menjadi salah satu perusahaan yang berimage baik dan terpercaya sehingga menarik minat investor untuk membeli saham dan pada akhirnya dapat meningkatkan volume perdagangan saham.

\section{Pengaruh Kinerja Keuangan terhadap Volume Perdagangan Saham}

Hasil analisis menunjukkan terdapat pengaruh negatif namun tidak signifikan antara kinerja keuangan terhadap volume perdagangan saham yang ditunjukkan dari nilai t-hitung $(0,268)$ lebih kecil dari t-tabel $(1,960)$ dan $p$-value $(0,790)$ lebih besar dari alpha 5\% (0,050). Untuk koefisien jalur $(\beta=-0,037)$ menunjukkan bahwa meningkatnya kinerja keuangan tidak akan mempengaruhi volume perdagangan saham secara signifikan sehingga hipotesis ditolak. Hasil penelitian ini menunjukkan bahwa dengan semakin meningkatnya kinerja keuangan berdasarkan keuntungan perusahaan yang diperoleh dari memanfaatkan keseluruhan aset perusahaan perbankan yang terdaftar di Bursa Efek Indonesia tidak mampu mempengaruhi aktivitas volume perdagangan saham. ROA hanya menjadi salah satu faktor. Ketika ROA berfluktuasi namun kesehatan bank secara keseluruhan dinilai baik maka hal tersebut tidak mempengaruhi aktivitas investor dalam kegiatan perdagangan saham. Investor mungkin lebih melihat kinerja keuangan secara keseluruhan melalui penilaian kesehatan bank. Serta, adanya kemungkinan praktek window dressing terhadap laporan keuangan tersebut agar kinerja perusahaan tampak lebih baik. Akibatnya investor kurang percaya karena informasi tersebut sering kali tidak menggambarkan kondisi perusahaan yang sebenarnya.

\section{Pengaruh Kinerja Sosial terhadap Volume Perdagangan Saham}

Hasil analisis menunjukkan terdapat pengaruh positif dan signifikan antara kinerja sosial terhadap volume perdagangan saham yang ditunjukkan dari nilai thitung $(2,171)$ lebih besar dari t-tabel $(1,960)$ dan $p$-value $(0,033)$ lebih kecil dari alpha 5\% (0,050). Untuk koefisien jalur $(\beta=0,301)$ menunjukkan bahwa meningkatnya kinerja sosial akan meningkatkan volume perdagangan saham secara signifikan, dan sebaliknya menurunnya kinerja sosial akan menurunkan volume perdagangan saham secara signifikan, sehingga hipotesis diterima. Hasil penelitian ini menunjukkan bahwa dengan semakin meningkatnya kinerja sosial perusahaan perbankan yang terdaftar di Bursa Efek Indonesia mampu mempengaruhi aktivitas volume perdagangan saham. Pengungkapan penerapan kegiatan CSR dapat mengirimkan signal promosi atau informasi lain yang menyatakan bahwa perusahaan tersebut lebih baik daripadaperusahaan lain karena peduli dengan dampak ekonomi, lingkungan dan sosial dari aktivitasperusahaan.

\section{Pengaruh Kinerja Keuangan terhadap Volume Perdagangan Saham melalui Harga Saham}

Hasil analisis menunjukkan terdapat pengaruh positif dan signifikan antara kinerja keuangan terhadap volume perdagangan saham melalui harga saham yang ditunjukkan dari nilai t-hitung $(2,004)$ lebih besar dari t-tabel $(1,960)$ dan $p$-value 
$(0,045)$ lebih kecil dari alpha 5\% (0,050). Untuk koefisien jalur $(\beta=0,164)$ menunjukkan bahwa meningkatnya kinerja keuangan akan meningkatkan volume perdagangan saham secara signifikan seiring dengan meningkatnya harga saham dan sebaliknya menurunnya kinerja keuangan akan menurunkan volume perdagangan saham secara signifikan seiring dengan meningkatnya harga saham, sehingga hipotesis diterima. Hasil penelitian ini menunjukkan bahwa dengan semakin meningkatnya kinerja keuangan perusahaan perbankan yang terdaftar di Bursa Efek Indonesia mampu mempengaruhi aktivitas volume perdagangan saham melalui peningkatan harga saham.

\section{Pengaruh Kinerja Sosial terhadap Volume Perdagangan Saham melalui Harga Saham}

Hasil analisis menunjukkan terdapat pengaruh positif dan signifikan antara kinerja sosial terhadap volume perdagangan saham melalui harga saham yang ditunjukkan dari nilai t-hitung $(2,005)$ lebih besar dari t-tabel $(1,960)$ dan $p$-value $(0,045)$ lebih kecil dari alpha 5\% (0,050). Untuk koefisien jalur $(\beta=0,164)$ menunjukkan bahwa meningkatnya kinerja sosial akan meningkatkan volume perdagangan saham secara signifikan, dan sebaliknya menurunnya kinerja sosial akan menurunkan volume perdagangan saham secara signifikan seiring dengan meningkatnya harga saham seiring dengan meningkatnya harga saham, sehingga hipotesis diterima. Hasil ini menunjukkan bahwa dengan semakin meningkatnya kinerja sosial perusahaan perbankan yang terdaftar di Bursa Efek Indonesia mampu mempengaruhi aktivitas volume perdagangan saham melalui peningkatan harga saham.

\section{Koefisien Determinasi Total}

Koefisien determinasi total menjelaskan mengenai seberapa besar model jalur (path) yang terbentuk dalam menjelaskan data yang digunakan dalam penelitian. Koefisien determinasi total yang didapatkan berdasarkan hasil perhitungan model path adalah sebesar 0,816 yang menunjukkan bahwa model path yang digunakan dapat menjelaskan sebesar $81,6 \%$ data yang digunakan dalam penelitian.

\section{PENUTUP}

\section{Kesimpulan}

1. Kinerja keuangan yang semakin tinggi mampu meningkatkan harga saham.

2. Kinerja sosial yang semakin tinggi mampu meningkatkan harga saham.

3. Harga saham yang semakin tinggi mampu meningkatkan volume perdagangan saham.

4. Kinerja keuangan tidak memiliki pengaruh terhadap aktivitas volume perdagangan saham.

5. Kinerja sosial yang membaik mampu meningkatkan volume perdagangan saham perusahaan.

6. Kinerja keuangan yang semakin tinggi mampu meningkatkan volume perdagangan saham melalui peningkatan harga saham perusahaan. 
7. Kinerja sosial yang semakin tinggi mampu meningkatkan volume perdagangan saham melalui peningkatan harga saham perusahaan.

\section{Saran}

1. Penelitian berikutnya disarankan analisa lebih lanjut mengenai rasio rasio lain yaitu penilaian kesehatan perusahaan perbankan yang diwujudkan dalam rasio likuiditas atau solvabilitas sehingga akan menghasilkan $R$ squared yang lebih tinggi karena adanya rasio jenis lain.

2. Penelitian berikutnya sebaiknya mempertimbangkan faktor-faktor yang berasal dari luar perusahaan antara lain tingkat inflasi, tingkat suku bunga, fluktuasi kurs, dan kondisi lingkungan yang mencakup kestabilan ekonomi dan politik sebagai bahan pertimbangan analisa sebelum mengambil keputusan untuk menginvestasikan dananya dalam bentuk saham.

\section{DAFTAR PUSTAKA}

Abdul dan Hidayat, N. 2000. Studi Empiris Tentang Pengaruh Volume Perdagangan Dan Return Terhadap Bid-Ask Spread Industri Rokok Di Bursa Efek Jakarta Dengan Model Koreksi Kesalahan. Jurnal Riset Akuntansi Indonesia. Vol.3, No.1, pp.69-85.

Afiff, S. dan Anantadjaya, S. P. D. 2013. CSR \& Performance: Any Evidence from Indonesian LQ45?. Review of Integratif Business Economics Resesearch. Vol.2, No.1.

Aldorino, Christeven; Rika Kharlina Ekawati, dan Cherrya Dhia Wenny. 2013. Pengaruh Corporate Social Responsibility Disclosure dan Kinerja Keuangan Terhadap Volume Perdagangan Saham pada Perusahaan Perbankan dan Asuransi di diakses BEI, dari http://eprints.mdp.ac.id/1337/1/Jurnal\%20Christeven\%20Aldorino\%202011 210046.pdf 2 Mei 2015

Ang, R. 1997. Pasar Modal Indonesia. Mediasoft Indonesia. Jakarta.

Astria, A. A. 2007. Analisis Pengaruh Kinerja Keuangan Terhadap Harga Saham Dan Volume Perdagangan Saham Pada Perusahaan Yang Masuk Dalam LQ45, Tesis, Program Pasca Sarjana Universitas Muhammadiyah Malang.

Bajaj, S. dan Dua, D. 2014. Investigation of Causal Relationship between Stock Prices and Trading Volume using Toda and Yamamoto Procedure. Eurasian Journal of Business and Economics. Vol.7, No.14, pp.155-181.

Bandi dan Jogiyanto, H. 1999. Perilaku Reaksi Harga Dan Volume Perdagangan Saham Terhadap Pengumuman Dividen. Simposium Nasional Akuntansi II Unibraw.

Brigham, E.F. dan Joel, H. 2006. Fundamental of Financial Management. Buku Satu. Salemba Empat. Jakarta.

Brigham, E. F. dan Daves, P. R. 2007. Intermediate Financial Management, $9^{\text {th }}$ edition. Thomson/South-Western. United States of America

Carroll, A.B. 1979. A Three-Dimensional Conceptual Model of Corporate Social Performance. Academy of Management Review. Vol.4. 
Cellier, A dan Chollet, P. 2010. The Impact of Corporate Social Responsibility on Stock Prices: An Event Study of Vigeo Rating Announcement.

Ghozali, I. 2011. Aplikasi Analisis Multivariate dengan Program IMB SPSS 19. Badan Penerbit Universitas Diponegoro. Semarang.

Haniffa, R. M. dan Cooke. T. E. 2005. The Impact Of Culture And Governanceon Corporate Social Reporting. Journal of Accounting and Public Policy. Vol.24, pp.391-430.

Helfert, E. A. 1996. Teknik Analisis Keuangan. PT Erlangga. Jakarta.

Hermawan, H. D. 2009. Pengaruh Kinerja Keuangan Dan Kinerja Sosial Terhadap Perilaku Investor (Studi empiris pada perusahaan yang tergabung dalam LQ-45 di BEI), Tesis, Program Pasca Sarjana Universitas Muhammadiyah Malang.

Igalens, J. dan J. Gond. 2005. Measuring Corporate Social Performance in France: A Critical and Empirical Analysis of ARESE Data. Journal of Business Ethics. Vol.56, No.2, pp.131-148.

Jogiyanto. 2008 . Teori Portofolio dan Analisis Investasi. BPFE. Yogyakarta.

Karimi, A. F. 2009. Corporate Governance dalam Mewujudkan Corporate Social Performance, http://ahmadfk.wordpress.com/2009. diakses 12 September 2015

Kasmir. 2008. Analisis Laporan Keuangan. PT Raja Grafindo Persada. Jakarta.

Laurensia, S. 2015. Pengaruh Kinerja Keuangan Terhadap Harga Saham Melalui Pengungkapan CSR Pada Perusahaan Konstituen Indeks Sri Kehati, AGORA. Vol.3, No 2, pp 491-497.

Monang, J. P. 1999. Pengaruh Kinerja Keuangan terhadap Volume Perdagangan Saham di Bursa Efek Jakarta, Tesis, Program Pasca Sarjana Universitas Diponegoro

Munawir. 2004. Analisa Laporan Keuangan, Edisi Keempat. Liberty. Yogyakarta.

Nuryaman. 2013. The Effect Of Corporate Social Responsibility Activites On Profitability And Stock Price (Studies On The Companies Listed On Indonesia Stock Exchange). Journal Of Global Management. Vol.6, No.1.

Pathirawasam, Chandrapala. 2011. The Relationship Between Trading Volume and Stock Returns. Journal of Competitiveness. No.3, pp.41-29.

Peter dan Robin. 2011. Pengaruh Volume Perdagangan dan Kinerja Keuangan Terhadap Harga Saham: Studi Emiten PT.Astra Agro Lestari,Tbk Di Bursa Efek Indonesia Pada Periode 2004-2007. Akurat Jurnal Ilmiah Akuntansi. No.5.

Riantani, S., Hartaya, T. dan Hasanah, A. 2011. Analysis of Debt to Equity Ratio and Return on Assets and its Effect to Closing Price of the Mining Industry listed in BEI. ACSSSR.

Sarwono, J. 2007. Analisis Jalur untuk Riset Bisnis dengan SPSS. Penerbit Andi. Yogyakarta.

Sugiyono. 2012. Metode Penelitian untuk Bisnis (Pendekatan Kuantitatif, Kualitatif, dan R\&D. Cetakan ke-15. Alfabeta, Bandung

Sukarno, G. 2008. Paper disajikan dalam Prosiding Seminar VI. Publikasi MMT.ITS, http://mmt.its.ac.id. 
Tandelilin, E. 2001. Analisis Investasi dan Manajemen Portofolio, Edisi Pertama. BPFE. Yogyakarta.

Tripathy, N. 2011. The Relation between Price Changes and Trading Volume: A Study in Indian Stock Market. Interdisciplinary Journal of Research in Business. Vol.1, Issue.7, pp.81-95. 